\title{
Government Expenditure on Human Capital Development: Implications for Economic Growth in Nigeria
}

\author{
OLUWATOBI, Stephen. O \\ Department of Economics and Development Studies, Covenant University \\ PMB 1023, Ota, Ogun State, Nigeria \\ E-mail: stephen.oluwatobi@yahoo.co.uk
}

OGUNRINOLA, I. Oluranti.

Department of Economics and Development Studies, Covenant University

PMB 1023, Ota, Ogun State, Nigeria

E-mail: olu.ogunrinola@covenantuniversity.edu.ng

Received: March 31, 2011

Accepted: April 24, 2011

doi:10.5539/jsd.v4n3p72

\begin{abstract}
This study examines the relationship between human capital development efforts of the Government and economic growth in Nigeria. It seeks to find out the impact of government recurrent and capital expenditures on education and health in Nigeria and their effect on economic growth. The data used for the study are from secondary sources while the augmented Solow model was also adopted. The dependent variable in the model is the level of real output while the explanatory variables are government capital and recurrent expenditures on education and health, gross fixed capital formation and the labour force. The result shows that there exists a positive relationship between government recurrent expenditure on human capital development and the level of real output, while capital expenditure is negatively related to the level of real output. The study recommends appropriate channeling of the nation's capital expenditure on education and health to promote economic growth.
\end{abstract}

Keywords: Human capital development, Capital and recurrent expenditure, Economic growth

JEL Classification: $\mathrm{H} 5$, O43

\section{Introduction}

Human capital has been recognized globally as one major factor that is responsible for the wealth of nations. According to Smith (1776) and Folloni and Vittadini (2010), human capital refers to the acquired and useful abilities of all the inhabitants or members of the society. The importance of human capital development to economic growth has been a motivating factor for scholars to examine the subject matter. For instance, several studies in Nigeria has examined, among other important issues, the nature of causality between human capital development and economic growth in Nigeria (Awe and Ajayi, 2010); the contributions of human capital to economic growth in Nigeria (Ogujiuba and Adeniyi, 2004; Omotor, 2004; Olaniyan and Okemakinde, 2008; Lawanson, 2009; and Diawara, 2009), the role of human capital in Nigeria's economic development (Dauda, 2010), and human capital development challenges in Nigeria (Ugal and Betiang, 2003). These studies provide both theoretical and empirical foundation for the contributions of human capital to economic growth.

However, in spite of the increased academic interest in the subject under discussion, several issues relating to the human capital development and economic growth relationship remain hitherto unsettled. Chief among these issues relate to the fact that the empirical linkage between human capital development and economic growth in Nigeria is yet unclear. This is because a good number of studies that have examined the influence of human capital development on the Nigeria's economic growth have generated varying outcomes (Lawanson, 2009; Ogujiuba and Adeniyi, 2004). Furthermore, while a long run relationship has been established between human capital development and economic growth in Nigeria, the impact of an aggregation of capital and recurrent expenditures on health and education respectively has not been sufficiently addressed by researchers. This study is therefore carried out to fill some of these gaps. It is designed to estimate the impact of human capital development on economic growth, ceteris paribus. The rest of this paper is organized as follows: Section 2 gives 
a brief review of literature, section 3 discusses the methodology of the study; in section 4 we specify and estimate the model of this study and in section 5 , and we conclude the paper.

\section{Literature Review}

One major challenge facing the global community is how to achieve sustainable development. According to the IMF (2002), sustainable development is made up of three pillars. They are economic development, social development and environmental protection. The essence of these pillars are to maintain and enhance the capacity and capability of future generations while meeting the needs of the present generation. To accomplish these multi-dimensional tasks, human capital should be strategically cultivated and positioned for the preservation of both the present and the future economic growth and development. Thus, according to Lyakurwa (2007), human capital development has the capacity to enlarge people's choices and opportunities, improve healthy living through acquired skills and knowledge and eventually enhance growth in the nation's gross domestic product through increased productivity.

The World Bank (2010) specifies that Nigeria has found it difficult to grow her economy in her quest to become a knowledge-based economy because of the challenges faced in the national educational system. According to the report, some major challenges limiting the advancement of Nigeria's education system are low tertiary enrolment level, teaching with obsolete methods, strikes and administrative hiccups, corrupt teachers asking bribes to pass students, frequent absence of teachers during teaching periods, lack of ICT infrastructure and other teaching methods, and poor funding. The organization categorized these problems into poor access to education, poor quality of education and poor funding of education.

Prior to the study undertaken by the World Bank's (2010), Odia and Omofonmwan's (2007) had reported that the Nigerian education system was constrained by several challenges, which included poor funding, poor educational infrastructure, inadequate classrooms, lack of teaching aids (such as projectors, computers, laboratories and libraries), dearth of quality teachers and unconducive learning environment. Moreover, they pointed that many social vices, such as examination malpractice, cultism, hooliganism, and corruption, have emerged from the school system. These in addition, compound the problems that impede the nation's ability to cultivate the kinds of people that can serve as tools to facilitate economic improvements.

One of the major concerns in the Nigerian education system, according to COLI (2001), is the challenge of integrating new knowledge into academic courses and programmes. The system operates on obselete knowledge thus finding it difficult to embrace new knowledge and discoveries. This leads to production of graduates who finds it difficult to fit into the world of work, since their acquired knowledge and skills are rarely relevant to the needs of employers of labour services. This problem is the result of lack of connection between the academia and the business work environment (World Bank, 2010), which has impeded the nation's capacity to build the critical mass of human capital required to facilitate growth.

Another challenge confronting knowledge and skill development in Nigeria is lack of funding. And in the case where there is funding, it is not efficiently allocated. Research and Development (R \& D), which facilitates the creation of knowledge to drive economic growth, is poorly funded by the government. The World Bank (2010) is of the view that government funding for university research is too low to attract partners in the economic and business work environment into R \& D agreements. This is unlike the case in Singapore, Korea and other advanced knowledge economies. Losing out on this partnership is contraining Nigeria's potential in breaking into a lucrative and job-creating economy (World Bank, 2010).

Ndulu (2010) examined the negative impact of human capital flight on economic growth in Nigeria. The study reported that the challenge of human capital in Africa is not limited only to low level of education and training, but it also includes the current inability of the country to retain a large proportion of its skilled and professional personnel. Thus, Nigeria has been losing a significant proportion of her skilled and professional manpower to other national market and increasingly depending on expatriate for many crucial functions.

Several other mitigating factors relating to human capital development emanate from the health sector. For instance, the Federal Ministry of Health (2005) reported that communicable diseases account for $72 \%$ of deaths while non-communicable diseases account for $21 \%$. It further reported that $38 \%$ of children are stunted, $29 \%$ are underweight, infant mortality rate is 100 deaths per 1000 , while under-5 mortality rate is 201 per 1000 . These reports are reflections that the health care system in Nigeria is currently weak, thus, limiting the chances of the people and impeding their capability to be part of contributing to the growth of the economy. According to WHO (2001), the preponderance of health-related problems could be attributed to the observed shortage of skilled medical workers at the level of primary health care. The study reported that only $41.9 \%$ of primary health care facilities provide antenatal and delivery services and $57.73 \%$ of these health facilities work without any midwife. 
Besides, $18.03 \%$ of such facilities operate without midwives or senior community health extension workers (SCHEWs). This calls for the need to support the health system with adequately trained workers in order to improve the provision of health services.

To address the challenges faced by human capital development in Nigeria, Odia and Omofonmwan (2007) recommended that the government should be more responsible with funding. Besides, private educational investors, teachers, parents, guidance and students should be re-oriented. They further suggested that technical education and innovation adaptation centres should be encouraged and properly financed to produce the quality of human capital required to develop the service sector and become a knowledge economy. Further, the World Bank (2010) recommends that recent initiatives such as the Nigerian University Network project, which aims at linking several universities - federal and private-and developing shared infrastructure for cooperation and cost-reduction, should be employed as a good start to address the challenges.

In order to address health care challenges in Nigeria, the Nigerian government has developed a Health Sector Reform (HSR) plan of action to guide investments and actions by all levels of government, the private sector, donors and all development partners in health. This plan aims at addressing primary health care, disease control, sexual and reproductive health, secondary and tertiary health care, drug production and management, coordination of development partners, organization and management. Furthermore, the Federal Ministry of Health has created the division of International Health to coordinate development aid to the health sector (WHO, 2001).

A study of the joint development of government expenditures and economic growth in 23 OECD countries conducted by Lamartina and Zaghini (2007) showed that there is a structural positive correlation between public spending and per capita GDP. Thus an increase in government's spending on human capital development is expected to culminate in an increase of per capita output.

Maku's (2009) study examines the connection between total government spending and economic growth in Nigeria over 30 years (1977-2006). He regressed real GDP on private investment, human capital investment, government investment and consumption spending. His result shows that human capital investment as a share of real output has positive but statistically insignificant effect on the growth rate of real GDP. He concluded that government expenditure had no significant influence on economic growth in Nigeria based on his analysis, which reveals that the variables have not maintained a uniform pattern in the period of study owing to persistent random shock effect on the time series. He reported that the rate of government expenditure to real GDP has been rising since the Structural Adjustment Programme (SAP) without significant contribution to economic growth in Nigeria. This he attributed to lack of government monitoring of the contract awarding process of capital projects, ineffective deployment of government funds to productive activities, and lack of transparency and accountability by the government on government spending. However, it is our view that if the study had used expenditure relating to human capital development (say, expenditure on education and health) he might have obtained a different result.

Ogujiuba and Adeniyi (2004) examined the impact of government education expenditure on economic growth. Their result showed a statistically significant positive relationship between economic growth and recurrent expenditure on education, while capital expenditure was wrongly signed and not significant in its contributions. Lawanson (2009) took this study further by including both the health and education expenditures in her model. Her objective was to examine the role of human capital investment (proxied by total government expenditure on education and health) on economic growth in Nigeria. After regressing GDP on government expenditure on education, government expenditure on health and the enrolment rates, she found out that a clear relationship exists between human capital development and economic growth. However, unlike the study by Ogujiuba and Adeniyi (2004), the study did not disaggregate expenditure figures on health and education into the recurrent and capital components.

Dauda (2010) made use of an adapted endogeneous growth model developed by Mankiw, Romer, and Weil (1992) in the study of human capital and economic growth relationship in Nigeria. However, the study did not include government spending as one of the human capital variables used in the model. Babatunde and Adefabi (2005) discovered a long run relationship between human capital development (proxied by schools' enrolments in primary and tertiary institutions and average years of schooling) and economic growth measured by outper per worker. Their result showed that education has a statistically significant positive relationship with economic growth. However, they did not give consideration to government health expenditure as a human capital component in the model specified and estimated. 


\section{Methodology}

Of the numerous studies on the relationship between human capital and growth, certain models have been specified. A more reliable adoption is the use of the augmented Solow human-capital-growth model. This model is an improvement on the Solow growth model. Solow's original model did not explicitly incorporate human capital. In order to do that, Mankiw, Romer, and Weil (1992) came up with the augmented Solow model. The justification for the inclusion of human capital in the model is the fact of non-homogeneity of labour in the production process either within a nation or across different economies due to their possession of different levels of education and skills. This modification facilitates the suitability and hence, the adaptation of this model for the Nigerian context.

The basic assumption in this approach is that increase in workers' quality through improved education, improves output. This supports the human capital theory which postulates that education and healthcare of workers ensure greater productivity (Olaniyan and Okemakinde, 2008). The augmented Solow model is therefore specified as:

$$
Y=A K^{\alpha}(h L)^{\beta}
$$

Where,

$\mathrm{Y}=$ Output level; $\quad \mathrm{K}=$ Stock of physical capital; $\mathrm{h}=$ Level of Human Capital; $\mathrm{L}=$ Labour, measured by number of workers; A=Level of Total Factor Productivity; $\alpha=$ Elasticity of capital input with respect to output; while $\beta=$ Elasticity of labour input with respect to output

Econometrically, the model is specified as follows:

$$
Y=A K^{\alpha}(h L)^{\beta} U
$$

When transformed into a log-linear form, it becomes,

$$
\log Y=\alpha_{0}+\alpha \log K+\beta \log h L+V
$$

Where $\alpha_{0}=\log A$ and $V=\log U$

To further suit the Nigerian context and the relevance of this study, we modified the model to accomodate other variables. These include government's capital expenditure on education and health $(\mathrm{CE})$ and government's recurrent expenditure on education and health (RE). These two variables are incorporated to capture governments investment in human capital development, since this study is focused on government's investment in human capital development and its effect on economic growth.

The new expanded model is thus stated as follows:

$$
\log Y=\alpha_{0}+\alpha_{1} \log K+\beta \log h L+\alpha_{2} \log R E+\alpha_{3} \log C E+V
$$

Output level (Y) is represented by real Gross Domestic Product (GDP); stock of physical capital (K) is measured by the country's Gross Fixed Capital Formation; hL which is a measure of total stock of human capital is a product of total school enrollment (h) and the total labour force (L). Human capital development is proxied by government's capital and recurrent expenditure on education and health care- that is CE and RE. It is expected that each of the explanatory variables would exhibit positive relationship with the dependent variable. The sources of data for this study are from the Statistical Bulletin (CBN, 2009); World Development Indicators (WDI, 2009), UNESCO and the United Nation's Statistical Division (UNSTAT). This study covers a period of 1970 to 2008.

\section{Model Estimation and Discussion of Results}

\subsection{Unit Root Test and Johansen cointegration}

This study engages a three-step procedure in order to determine the relationship between human capital development and economic growth in Nigeria. These procedures are unit root test, Johansen co-integration technique and Error Correction Mechanism. The Augmented Dickey Fuller (ADF) and Philip-Perron (PP) tests were engaged to test for the stationarity of the time-series data used in this study. Further, the Johansen co-integration test and the error correction modeling were employed to find out the long run equilibrium convergence and the speed of disequilibrium adjustment respectively. Table 1 shows the result of the stationarity test on the data series.

Table 1 shows that not all the variable is stationary at levels. Thus, another test is conducted at $1^{\text {st }}$ difference. The result is presented in Table 2 below. It is obvious from Table 2 that all the variables are stationary at first difference. When variables that are known to be I(1) produce a stationary series, there is the feasibility of 
cointegration among them in the long run. To establish the existence of long run relationship among the variables, a cointegration test is performed using the Johansen's cointegration test. This is reported in Table 3.

From Table 3, the Trace statistics, Max-Eigen value and MacKinnon-Haug-Michelis (1999) p-values show that the null hypothesis of no cointegration was rejected in favour of the alternative hypothesis at 0.05 level. The Trace statistics further shows that the null hypothesis of at most one cointegrating equation, at most two cointegrating equations and at most three cointegrating equations among the variables were rejected in favour of the alternative hypothesis at 0.05 level. Their values, as indicated in the table are greater than the critical values at 0.05 level. This means that there exists long run relationship among the variables. The Trace test indicates four cointegrating equations while the Max-Eigen test indicates one cointegrating equation. However, in this study the indication of the Max-Eigen test is followed. It is therefore shown, in Table 4, that there is one cointegrating equation in the series, according to the Max-Eigen test result.

The results from the cointegrating equation in Table 4 reveal that all the variables are significant at 0.05 level in the equation. The equation shows that recurrent expenditure on human capital (RE) and gross physical capital formation $(\mathrm{K})$ have positive relationship with the level of economic activity (Y). This implies that in the long run, the sizes of recurrent expenditure on human capital as well as the size of physical capital have positive impact on the level of economic activity. These are in line with a priori expectations. The degree of impact shows that $1 \%$ change in recurrent expenditure on education and health results in $0.15 \%$ change in the level of real output. Further, $1 \%$ change in physical capital will result in $0.9 \%$ change in the real output level in the economy.

On the other hand and contrary to the a priori expectations, the stock of human capital (hL) and government's capital expenditure on education and health care (CE) have negative relationships with the level of real output (Y). The result thus states that $1 \%$ change in government capital expenditure on human capital (CE) as well as on the stock of human capital (hL) will result in $0.29 \%$ and $0.77 \%$ change in the level of real output in the opposite direction. Thus both $\mathrm{CE}$ and $\mathrm{hL}$ are significantly negative in their relationship with the level of economic activity, contrary to a priori expectations. However, since the model is in the double-log form, the coefficient estimates can be interpreted in terms of elasticity. Thus, all the explanatory variables are inelastic with respect to their relationship with the dependent variable Y.

\subsection{Causality Tests for Vector Error Correction Modeling}

This study examined the short-run dynamics between the variables in the cointegrating equation by estimating the error correction model. This estimation is presented in Table 5.

It is observed from the result that the coefficient of the error correction term (ECM) has the expected negative sign and it lies between zero and one and statistically significant at 5\% level. The significance of the error correction mechanism supports cointegration and suggests that there exists long run steady-state equilibrium between the level of real output (Y) and the explanatory variables. The ECM indicates a feedback of approximately $75 \%$ of the previous year's disequilibrium from long run elasticity of the explanatory variables. That is, the coefficient of the error correction term measures the speed at which the level of real output adjusts to changes in the explanatory variables in an effort to achieve long run static equilibrium. It can be said therefore that the speed of adjustment is high.

\section{Summary of Findings, Recommendations and Conclusion}

This study has shown that there exists a long run relationship between the variables used as proxy for human capital development - $\mathrm{CE}$ and RE - and economic growth in Nigeria. Thus, economic growth in Nigeria depends on human capital, among others, in the long run. The result shows that physical capital (K) and government recurrent expenditure on human capital (RE) are positively correlated with the level of real output, while there exists a negative relationship between government capital expenditure in human capital (CE) and the level of real output (Y). The reason for this relationship can possibly be traceable to the much reported corruption and misappropriation of public funds (Transparency International, 2011) allocated for capital projects such as the installation of educational and health infrastructure in Nigeria. As at 2010, Nigeria scored 2.4 out of 10 in terms of transparency and the country made a position of 134 out of 178 (Transparency International, 2010).

Also from the result of the study, it was discovered that a statistically significant negative relationship exists between the stock of human capital $(\mathrm{hL})$ and the level of real output $(\mathrm{Y})$. Though this runs counter to a priori expectations, yet there could be some plausible explanations for this. In the first place, the inverse relationship could be that the human capital 'production process' is wrong, leading to the currently high level of graduate unemployment in Nigeria (Kolawole and Arikpo, 2004, NBS 2010). The studies of Ohiwerei (2009) and Igwilo (2010) buttress this fact as they also confirm the widely-held view of limited employability of many Nigerian 
graduates. Furthermore, according to Dabalen, Oni, and Adekola (2000), employers complain that graduates are poorly prepared while academic standards have fallen considerably making most university degree holders mere certificate holders as opposed to being competent and skilled manpower resources. This view is in line with that of Olaniyan and Okemakinde (2008) who have also noticed similar trend and recommended improvement in the quality of human capital produced in the country. Thus, it is our recommendation that the development of new educational curricula in line with national manpower needs be made a national priority in our institutions of learning. Such new educational curricular should be the joint responsibility between the educational institutions and the industrial sector of the economy. This collaborative approach to the solution of manpower problem is expected to be a benefit to the entire economy and therefore enhance the expected national growth.

With respect of capital expenditure on human capital development, a new approach, based perhaps on partnership between the private and public sectors of the economy should be put in place. This is required to enhance the necessary transparency and accountability required for disbursement and utilization of funds for capital projects in educational development. Putting this framework in place would engender value addition (from capital expenditures on human capital development) to economic growth.

Based on the findings of the study, the following conclusions are drawn:

Firstly, there exists a long run relationship between human capital development and economic growth in Nigeria. Secondly, an effective reform is required to guide the disbursement and control of funds for capital projects in the education sector. Thirdly, the Nigerian education system is faulty leading to poor quality of human capital, graduate unemployment, and un-employability of Nigerian graduates. Hence, they cost the economy for maintaining them, without their own significant contribution to economic growth.

Further studies can therefore focus on Public-Private Partnerships (PPP) and human capital investment in Nigeria with particular focus on capital projects.

\section{References}

Akingbade, B. (2005). Meeting the Challenges of Human Capital Development in Nigeria: The Case for Reforms in our Educational Policies and Systems.

Ariyo, D. (1999). Developing a Knowledge-Driven Nigerian Economy: An Economic Framework for the 21st Century. Africa Economic Analysis.

Awe, A. A., \& Ajayi, S. O. (2010). The Nexus Between Human Capital Investment and Economic Growth in Nigeria. Pakistan Journal of Social Sciences , 1-7.

Babatunde, M. A., \& Adefabi, R. A. (2005). Long Run Relationship Between Education and Economic Growth in Nigeria: Evidence From the Johansen's Cointegration Approach. Education in West Africa: Constraints and Opportunities. Dakar: Cornell University.

Becker, G. (1994). Human Capital: A Theoretical and Empirical Analysis with Special Reference to Education. Chicago: University of Chicago Press.

Bhutoria, N. (2000). Valuation of Human Capital. HR folks.

COLI. (2001). Building Capacity to Deliver Distance Education in Nigeria's Federal University System. Vancouver: World Bank.

Dabalen, A., Oni, B., \& Adekola, O. (2000). Labor Market Prospects of University Graduates in Nigeria. World Bank.

Dauda, R. O. (2010). Role of Human Capital in Economic Development: An Empirical Study of Nigerian Case. Oxford: Oxford Business and Economics Conference Program.

Diawara, B. (2009). Can Spending on Education by Donors and National Governments Help Enhance Education Performance in Africa? International Journal of African Studies , 31-46.

Federal Ministry of Health. (2005). Health Promotion Policy for Nigeria. FMOH.

Ghani, E., \& Kharas, H. (2010). Service Revolution. South Asia: World Bank.

Harbison, F. H. (1973). Human Resources as the Wealth of Nations. New York: Oxford University Press.

Igwilo, M. (2010). Globalizing the Curriculum or Humanizing the Curriculum: Matters arising in the Search for a Viable Education in Nigeria. International Journal of Academic Research , 1-5.

IMF. (2002). Development, Social Development and Environmental Protection. IMF.

Jhingan, M. L. (2005). The Economics of Development and Planning. Delhi: Vrinda. 
Kolawole, C. O., \& Arikpo, P. A. (2004). Predictors of Self-Employment Efforts Among Unemployed Nigerian graduates.

Lamartina, S., \& Zaghini, A. (2007). Increasing Public Expenditures: Wagner's Law in OECD Countries. Rome. Lawanson, O. I. (2009). Human Capital Investment and Economic Development in Nigeria: The Role of Health and Education. Oxford: Oxford University.

Lyakurwa, W. M. (2007). Human Capital and Technology for Development: Lessons for Africa. AfDB.

Maku, O. E. (2009). Does Government Spending Spur Economic Growth in Nigeria? Munich: MPRA.

Mankiw, N. G., Romer, D., \& Weil, D. N. (1992). A Contribution to the Empirics of Growth. Quarterly Journal of Economics , 408-437.

Meier, G. M. (2001). The Old Generation of Development Economists and the New. In T. W. Bank, Frontiers of Development Economics: The Future in Perspective (pp. 13-50). Washington D.C.: Oxford University Press, Inc.

NBS.(2010): Statistical News: Labour Force Sample Survey, 2009; Abuja, Nigeria

Ndulu, B. J. (2001). Human Capital Flight: Stratification, Globalization and the Challenges to Tertiary Education in Africa. World Bank.

Odia, L. O., \& Omofonmwan, S. I. (2007). Educational System in Nigeria: Problems and Prospects. Journal of Social Sciences , 81-86.

Ogujiuba, K. K., \& Adeniyi, A. O. (2004). Economic Growth and Human Capital Development: The Case of Nigeria. Nigeria: CBN.

Ohiwerei, F. O. (2009). Job Prospect for Business Educators University Graduates in Nigeria. Current Research Journal of Social Sciences , 70-73.

Olaniyan, D. A., \& Okemakinde, T. (2008). Human Capital Theory: Implications for Educational Development. European Journal of Scientific Research, 157-162.

Omotor, D. G. (2004). An Analysis of Federal Government Expenditure in the Education Sector of Nigeria: Implications for National Development. Journal of Social Sciences , 105-110.

Oyejide, A. T., \& Bankole, A. S. (2001). Liberalisation of the Services Sector in Nigeria: Implications of Unilateral and Multilateral Approaches. Nigeria: AERC.

Psacharopoulos, G., \& Woodhall, M. (1997). Education for Development: An Analysis of Investment Choice. New York: New York Oxford University press.

Radwan, I., \& Pellegrini, G. (2010). Knowledge, Productivity and Innovation in Nigeria: Creating a New Economy. Washington D. C.: The World Bank.

Sakamota, A., \& Powers, P. A. (1995). Education and the Dual Labour Market for Japanese Men. American Sociological Review, 222-246.

Schultz, T. (1961). Investment in Human Capital. American Economic Review, Vol45, No. 57.

Sen, A. (1999). Development as Freedom. Oxford: Oxford University Press.

Smith, A. (1776). An Inquiry into the Nature and Causes of the Wealth of Nations Book 2 - Of the Nature, Accumulation, and Employment of Stock. Forgotten Books.

The World Bank. (1995). Beyond Economic Growth: Growth of the Service Sector. The World Bank.

The World Bank. (2010). Knowledge, Productivity and Innovation in Nigeria: Creating a New Economy. Washington D. C.: The World Bank.

Todaro, M. P., \& Smith, S. C. (2009). Economic Development. Prentice Hall.

Transparency International. (2011). Corruption Perception Index 2010 Results; http://www.transparency.org/policy_research/surveys_indices/cpi/2010/results; Accessed April 21, 2011.

Ugal, D. B., \& Betiang, P. A. (2003). Challenges for Developing Human Capital in Nigeria: Global-Local Connection.

WHO. (2001). WHO Country Cooperation Strategy: Federal Republic of Nigeria. Brazzaville: WHO.

World Bank. (1999). Knowledge for Development. World Bank. 


\section{APPENDIX}

Table 1. Test of Stationarity at Levels

\begin{tabular}{|l|l|l|l|l|l|}
\hline & \multicolumn{2}{|c|}{ ADF } & \multicolumn{2}{|c|}{ PP } & \\
\hline SERIES & $\begin{array}{l}\text { Intercept with no } \\
\text { trend }\end{array}$ & $\begin{array}{l}\text { Intercept with } \\
\text { trend }\end{array}$ & $\begin{array}{l}\text { Intercept with no } \\
\text { trend }\end{array}$ & $\begin{array}{l}\text { Intercept with } \\
\text { trend }\end{array}$ & Remarks \\
\hline LnY & 0.521919 & -2.014038 & 0.375786 & -2.073613 & $\mathrm{NS}$ \\
\hline LnK & 0.328728 & -1.820589 & 0.328728 & -1.932999 & $\mathrm{NS}$ \\
\hline LnhL & -1.577310 & -2.878577 & -1.448503 & -1.737302 & $\mathrm{NS}$ \\
\hline LnCE & -1.995458 & -3.338296 & -2.878173 & -4.560103 & $\mathrm{NS} \mid \mathrm{NS} / \mathrm{S}$ \\
\hline & & -3.959618 & 0.221245 & $\mathrm{NS} / \mathrm{S}$ \\
LnRE & -0.567232 & -7.014470 & $\mathrm{NS} / \mathrm{S}$ \\
\hline \multicolumn{7}{|l|}{ Critical Values at 5\% level of significance } \\
\hline Levels & -2.941145 & -3.533083 & 2.941145 & -3.533083 & \\
\hline
\end{tabular}

Note: A variable is stationary when ADF or PP values are greater than the critical value. NS and S mean non-stationary and stationary respectively.

Table 2. Test of Stationarity at First Difference

\begin{tabular}{|l|l|l|l|l|l|}
\hline \multicolumn{3}{|c|}{ ADF } & \multicolumn{2}{c|}{ PP } & \\
\hline SERIES & $\begin{array}{l}\text { Intercept with } \\
\text { no trend }\end{array}$ & $\begin{array}{l}\text { Intercept with } \\
\text { trend }\end{array}$ & $\begin{array}{l}\text { Intercept with } \\
\text { no trend }\end{array}$ & $\begin{array}{l}\text { Intercept with } \\
\text { trend }\end{array}$ & Remarks \\
\hline LnY & -4.905598 & -4.973756 & -4.912491 & -4.972613 & $\mathrm{I}(1)$ \\
\hline LnK & -4.952845 & -4.986793 & -4.952845 & -5.009271 & $\mathrm{I}(1)$ \\
\hline LnhL & -4.294709 & -4.454412 & -4.440888 & -4.530117 & $\mathrm{I}(1)$ \\
\hline LnCE & -7.890473 & -7.877809 & -7.854410 & -7.821965 & $\mathrm{I}(1)$ \\
\hline LnRE & -7.760098 & -7.641527 & -19.34813 & -18.75239 & $\mathrm{I}(1)$ \\
\hline \multicolumn{7}{|l}{ Critical Values at 5\% level of significance } \\
\hline $\mathbf{1}^{\text {st }}$ Difference & -2.943427 & -3.536601 & -2.943427 & -3.536601 & \\
\hline
\end{tabular}

Note: A variable is stationary when ADF or PP values are greater than the critical value.

Table 3. Test of Cointegration among Series

\begin{tabular}{|l|l|l|l|l|l|l|l|}
\hline $\begin{array}{l}\text { Hypothesized } \\
\text { No. of CE(s) }\end{array}$ & Eigenvalue & $\begin{array}{l}\text { Trace } \\
\text { Statistics }\end{array}$ & $\begin{array}{l}\mathbf{0 . 0 5} \\
\text { Critical } \\
\text { Value }\end{array}$ & Prob** & $\begin{array}{l}\text { Max-Eigen } \\
\text { Statistic }\end{array}$ & $\begin{array}{l}\mathbf{0 . 0 5} \\
\text { Critical } \\
\text { Value }\end{array}$ & Prob** \\
\hline None & 0.692585 & $115.7726^{*}$ & 76.97277 & 0.0000 & $42.46398^{*}$ & 34.80587 & 0.0051 \\
\hline At most 1 & 0.539304 & $73.30864^{*}$ & 54.07904 & 0.0004 & 27.90057 & 28.58808 & 0.0610 \\
\hline At most 2 & 0.446438 & $45.40807^{*}$ & 35.19275 & 0.0029 & 21.28977 & 22.29962 & 0.0687 \\
\hline At most 3 & 0.408296 & $24.11831^{*}$ & 20.26184 & 0.0140 & $18.89093^{*}$ & 15.89210 & 0.0164 \\
\hline At most 4 & 0.135155 & 5.227376 & 9.164546 & 0.2594 & 5.227376 & 9.164546 & 0.2594 \\
\hline
\end{tabular}

Trace test indicates 4 cointegrating equations while Max-Eigen test indicates 1 cointegrating equation; both at the 0.05 level.

*denotes rejection of the hypothesis at the 0.05 level

**MacKinnon-Haug-Michelis (1999) p-values

Table 4. Long run Normalized Cointegration Estimates

$$
\text { Log likelihood } \mathbf{- 3 9 . 4 3 8 7 5}
$$

\begin{tabular}{|l|l|l|l|l|l|}
\hline \multicolumn{7}{|c|}{ Log likelihood $\mathbf{- 3 9 . 4 3 8 7 5}$} \\
\hline LnY & LnK & LnRE & LnhL & LnCE & C \\
\hline 1.000000 & $-0.902699^{*}$ & $-0.151111^{*}$ & $0.771874^{*}$ & $0.295689^{*}$ & -0.114632 \\
& $(0.07711)$ & $(0.04594)$ & $(0.24852)$ & $(0.04546)$ & $(0.03000)$ \\
\hline
\end{tabular}

*denote statistical significance at 5\%. 
Table 5. Vector Error Correction Model for level of Real Output

\begin{tabular}{|l|l|l|l|l|l|}
\hline Variable & LnY & LnRE & LnK & LnhL & LnCE \\
\hline ECM & $-0.750964 * *$ & $-0.919842 * *$ & $-3.499764 *$ & -0.099648 & -1.302566 \\
& $(-2.15991)$ & $(-2.44638)$ & $(-4.24512)$ & $(-1.00050)$ & $(-1.70179)$ \\
\hline
\end{tabular}

$*$ and $* *$ represent $1 \%$ and $5 \%$ significance levels respectively; t-statistics in ( ) 